\title{
A N A D DRESS
}

DELIVERED BEFORE THE

\section{OSWEGO COLNTIT AGRIOUITLRAL SOCIETIT}

AT MEXICO, SEPTEMBER 11, AND BEFORE THE

\section{PRANKLIN GOLNTY AGRIOULTURAL SOGETIY}

AT MALONE, SEPTEMBER 13, 1861.

\author{
BY LUTHER H, TUCKER.
}

Published at the Request of these Societies.

A L B A N Y :

PRINTED BY C. VAN BENTHUYSEN. 1861. 



\title{
A N A DDRES
}

DELIVERED BEFORE THE

\section{OSWEGO COLNTI AGRIOUITLRHL SOCERTI}

AT MEXICO, SEPTEMBER 11,

AND BEFORE THE

\section{PRANKLIN COLVTY AGRICULTURAL SOCEETY}

AT MALONE, SEPTEMBER 13, 1861.

\author{
BY LUTHER H. TUCKER.
}

Published at the Request of these Societies.

A L B A N Y :

PRINTED BY C. VAN BENTHUYSEN.

1861. 


$$
5^{5} 2^{3}
$$

By transfor

- $13 \quad 06$ 


\section{ADDRESS.}

Gentlemen-War times have generally been times of diminished production and enhanced prices. Large numbers are commonly drawn from their labors on the harvest field, in gathering in the means of life, to take up, on the battle field, the implements of death. The present struggle to subvert the Constitution of our fathers, to trample under foot the laws and liberties of our Union, fortunately-or, should I not rather say, providentially - found the loyal portion of the country with granaries filled to their utmost, from the proceeds of the farmer's toil, and with bank-coffers also unprecedentedly full, from the proceeds of that vast surplus for which the wants of other nations have opened a ready market. At no former period in our history, in all probability, have we ever been so well provided both with food, which is the life-blood, and with money, which has been termed the sinews, of a war; with few, if any exceptions, beyond the single season of 1860 , have we ever had crops aggregating a production so great as those which have just been cut and housed, so far as their extent can now be estimated. In Great Britain and on the Continent of Europe, on the other hand, the general character of the present year, although more propitious than the disastrous season by which it was preceded, has scarcely anywhere been such as to return a full average yield; and there is, consequently, every prospect of the continuance of a considerable foreign demand,-rendering the North every day stronger and stronger, pecuniarily, for the suppression of the insurgent movement, while at the same time conferring: upon the Farmer a degree of independence enjoyed by no other class or pursuit among as. And yet, shut off as we were so suddenly from the Southern market, by the political tempest; with the current prices for our grain and dairy products falling, like the mercury before a thickening storm; with the gloom of the contest apparently growing darker and darker, and the certainty 
constantly becoming more apparent and more absolute, that we were to look for no mere summer shower,- - some of us had perhaps begun to be discouraged lest the requirements of our armies and of other nations should fail to be sufficient to consume the crops we have produced, and pay us for them at remunerative rates.

\section{Low Prices Necessitate Better Farming.}

We meet, gentlemen, on such anniversaries as this, not alone for competition, one with another, as regards the practical achievements which each has been working out in the past, but also to receive and impart suggestions for the future, to encourage one another in further improvement, to obtain what light we can upon the means by which this improvement is to be brought about. Much of the wonderful advancement which has characterized English Agriculture during the present century has been justly ascribed, as you will remember, to the high rents which the English farmer has been obliged to pay-compelling him to unceasing exertion and the adoption of thorough-going system; forcing him to count the cost of every operation, in order to reduce it-or, if necessary, to enlarge it, for one may sometimes be as good policy as the other-with the object of securing returns proportionably increased; - in fine, to sift out, so far as possible, every sort of loss and waste, positive or negative, in order to make a profit out of farming by the sheer exercise of skill, where, without such management, failure and ruin were inevitable. A somewhat similar compulsion, arising from the virgin wealth of the vast prairies in our newer States, when competing with our older and less cheaply cultivated soils at the East-a compulsion which bids fair, in any event, to become constantly more and more urgent,- - has been for some time tending, I think, to give a similar impetus to improvement here: and now that we have been placed amidst new circumstances to derange our markets, and to reduce, for the time being at least, the money value of our crops, it becomes a matter of great practical interest for us, to consider whether there is not a lesson of farther good to be derived from the present condition of affairs; -whether this cloud, also, has not its "silver lining;" whether, in fact, paradoxical though it may appear, LOw PRICES should not really be regarded as indicements to Better farming. We have entered bravely upon the task of showing to the world the 
degree of Military spirit we possess : animated by a glorious patriotism, three hundred thousand men, or more, have already gone forth to fight in support of the best form of government mankind has ever seen; would that we might also prove that the Resources of our Agriculture have never yet been fairly estimated, or fully tested, and that while the dignity and perpetuity of our Institutions are being vindicated by the strong arm of the soldier, we, the farmers of the country, may at the same time support its armies, and enlarge its wealth, by the adoption of a more enlightened, a more economical, a more productive, and a more progressive system of Husbandry.

\section{Are we to Anticipate the Continuance of Low Prices?}

I have spoken of low prices, as if they were to continue as they now are; and if such should be the case, could we not safely predict that the farmers of New York would be the most independent and prosperous of all her citizens? But, unless the war is brought to its conclusion before it has time to produce a sensible effect upon the Agricultural production of the country, which we, perhaps, have now no reason to anticipate, it will be strange if its ultimate result is not to interfere with sales of Wheat, for example, at less than a dollar a bushel - of Butter at less than a shilling a pound. Indeed, so universally has it been the result of War to diminish the Agricultural production of a country so engaged, that the London "Mark Lane Express," the leading organ of the English grain trade-in the face of our large surplus from the crop of 1860 and apparently favorable prospect for 1861 ,- -has repeatedly urged upon the attention of its readers, during the past few months, the assumed fact that Great Britain cannot long look to America for the breadstuffs she is obliged to purchase.* And, aside from the effect the existence of the war, may, or may not, have upon the crop of 1862 , it is perhaps hardly to be anticipated, that the whole country will again enjoy the general exemption from dangers of drouth or frost, of damaging storms or destructive insects, which has so generally characterized this and the previous year, and given us, with rare

* See the " Mark Lane Express" under date of May 27, July 15 and July 29, among other numbers, for leading editorials referring to this subject; and, as recently as the number of Sept. 30, a correspondent of the same journal, dating from New York, argues at length that " this is likely to be the last year that England may expect any shipments of breadstuffs to a large amount" from the United States! 
exceptions, both East and West, returns so remarkable and so free from serious injury. Adopting this train of thought, we are again led to the conclusion that the Eastern farmer should strain every nerve for a spirited campaign in 1862 ; and if, owing to the causes just referred to, prices should then advance, he will be ready to avail himself of the benefit of this advance,-subject to no delays and expenses arising from the transportation which taxes his Western competitor so heavily-free from those risks and losses which have endangered or engulphed the fortunes of so many, engaged in other pursuits, more pretentious perhaps, but inherently less sound and stable than his own. On the other hand, should the smiles of Providence again rest upon our whole territory, from Massachusetts Bay to the banks of the Mississippi, again clothing every field in abundant plenty,-the Farmer here will certainly be none the worse for having taken every precaution to secure as large crops of every kind, as his land can be made to yield,--and our Country will be none the worse, if, out of such profusion, we should once more be able to undersell the Farmers of every other nation, in the great grain markets of the world, and thus maintain that westward flow of the precious metals, which we need so much to meet our heavy war expenditure, and to add to the current wealth in circulation among us.

The Course of our Agriculture in the Past.

But, gentlemen, on the eve of such a struggle as that which we have now entered upon, is it not the part of wisdom to take a brief retrospect of the Past? For nearly fifty years we have enjoyed the almost uninterrupted blessings of Peace, with every advantage for prosperity and improvement. For thirty years Agricultural Periodicals have been in circulation among us, reporting the successes of our best farmers--indeed, employing their own pens to disseminate, in every section of the State and Country, the systems most successfully adopted in any one locality. For twenty years the Farmers of New York have annually met in competition at our State Fairs, and the great brotherhood of County and Town Societies has been growing up, carrying increased intercourse and a greater rivalry, not only to every neighborhood, but almost to every farm. And yet to-day, is it quite without hesitation or doubt, that we can ask - Has our Agriculture, as a whole, improved or not? Has the production of the State, in proportion to the number of acres 
farmed, advanced or retrograded? Do our methods of culture and the crops we obtain, compare more or less favorably in $\mathbf{1 8 6 1}$, than in 1821, with the systems and the productiveness of Great Britain, at these two periods? Does our farming pay? and are its profits any larger or more secure, now than heretofore? These are questions which we should all do well to ponder-they are questions which come home to the business and the bosoms of us all. How can we face duller markets and lower priceshow can we take heart to renew the labors which the succession of the seasons never fails to bring with it in their order, without knowing whether we have really been accomplishing anything more or better in the past, than our fathers did before us - whether Agriculture has been a backslider or a laggard, while every other Art has gone forward,- the Farmer growing poorer, or remaining at a stand-still, while his compeers in every other pursuit have been laying by a competence or accumulating wealth?

\section{Is our Farming of a Paying or Progressive Kind?}

These questions are urged upon our attention, moreover, because there are certain statements in current circulation, which are, as I believe, partially unfounded, or very greatly exaggerated, and calculated to do injury rather than good. One class of the statements alluded to, emanates quite frequently from among farmers themselves. "Farming," they will tell you, "does not pay. It is a life of slavish toil-of unceasing and illrewarded exertion - of hazards in profit and exposure of person -of few pleasures and many pains." Accordingly we find the children of those who express such opinions, as soon as the welcome age of manhood comes, branching off into any other pursuit rather than follow that which their fathers have always taken pains to render both discouraging and repulsive to them. Another class of the statements mentioned, we constantly hear from would-be scientific gentlemen,-who may perhaps have patent manures to sell, or letters of advice to give at a reasonable fee,or soil analyses to make - very cheap, and very valueless. They tell us that we are rapidly exhausting our soils. That our wheat crops formerly averaged 25 bushels per acre where they now average from 8 to 12 bushels.* That the ruin of our soils

* This assertion, from whatever source it may have originated, has acquired great currency, and is so commonly repeated - often by those whose reputation as authorities 'has shielded it from criticism-that it seems to be now received almost as an accepted fact. It 
and ourselves is certainly impending, unless we adopt their specifics, and come and sit at their feet for instruction. I would not even appear to decry the services or the dignity of sciencemuch less to depreciate the importance of knowledge, or discourage the more thorough education of our young farmers; but let us be very wary of pretenders, remembering always that quackery is no stain upon the shield of true science, and that even she herself cannot point out to us any "royal road" to thorough farming, which is not in accordance with the truths of our every-day experience, or which shall relieve us from the necessity of constant observation and the skillful management of our affairs.

\section{Money-Making in any Pursuit mainly Dependent upon INDUSTRY AND SkILL.}

In speaking of the profits and pleasures of farming, we must put it upon the same level as we should an occupation of any other kind. Suppose I address my neighbor, the tailor, or the shoemaker, and ask if tailoring or shoemaking pays, and is an agreeable way of life? Suppose I turn to the merchant or the lawyer, and inquire whether over the counter or before the court, there is money to be made and enjoyment to be won? In either of these cases, or in any similar case, it is easy to predict the answer, when you are questioning a man of industry, of a reasonable degree of economy, ability and skill, who has a taste for the pursuit in which he is engaged. Indeed, with success, there almost always comes a taste for that which is the source of success, if, as is not impossible, it may not have previously existed in a very prominent way. But go, on the other hand to a shiftless mechanic, a careless, credit-less merchant, an indolent or blundering lawyer, and you will be sure to learn that either of these employments is an inevitably laborious and losing

occurs as a stereotyped phrase in our Agricultural books, papers and addresses. Perhaps at first intended to show the injury sustained by some of our farmers from the Hessian fl $s$ and Wheat midge, it is now brought forward uniformly, to prove the deterioration of our soils; extended, as applying to the whole State, and exaggerated in various ways, apparently according to the fancy of the person using it. Thus the "Mark Lane Express" in one of the articles already referred to, gravely says of our wheat lands on its own editorial responsibility: "Even in New York State the falling off is very great. Lands that produced a few years back 25 bushels per acre, now barely average 5. In Albany district, lands that formerly yielded from 30 to 40 bushels have sunk to $7 \frac{1}{2}$ bushels, and in some counties to five and six.", 
one, if not also intensely disgusting and disagreeable! It is the bad workman quarrelling with his tools. There are of course exceptions, here, as to other rules. But in farming, as in the other established occupations of mankind, we are nevertheless obliged to conclude that when it fails to be reasonably remunerative, the fault must be in the particular individual or circumstances, not in the class and pursuit to which they belong.

\section{The Deterioration of our Soll and Crops Unsupported in Fact-Importance of Agricultural Statistics.}

In speaking of the improvement or retrogression of our Farming, of the deterioration or non-deterioration of our soils, -it is to be deeply regretted that there should be so much ground as there undoubtedly is, for the assertions alluded to. There can be no dispute that many farms have been worn down almost to the last degree of apparent exhaustion, by mismanagement and rapacity. At the same lime, the ranks of good farmers are filling by degrees; and, to take the whole of this State together, I am very much inclined to discredit any statement which should make out either its average or its aggregate production greater, either as regards the number of acres or the average produce per acre, at any former period in its History, than it is to-day. I can find no statisties which justify such an assertion. But I must agnin express the regret that this can only be matter of opinion, based upon such opportmities of intercourse as I have had with observant men in different localities, so long as we have no system for the annual collection of Agricultural Statistics. It is not alone questions of merely speculative interest which such statistics would enable us to decide: but each year and each generation would thus place on record, for the benefit of succeeding years and generations, the encouragement of its successes, the monition of its mistakes; and many matters of vague opinion would by degrees be brought, approximatively at least, to a definite understanding and settlement. And yet it is our farmers who are mainly, if not solely, responsible for the failure of the several legislative attempts that have been made to secure the collection of our Agricultural Statistics. Here we should be ashamed to find the Empire State behind Ohio, which for ten years past has been setting us an example in this regard; and I am constantly assured by those conversant with the Agriculture 
of that State, of the satisfaction its $\Lambda$ gricultural Statistics have given, in realizing all or more than all the benefits that had been anticipated from them. But their real value cannot be fully appreciater, until the system has been carried on for a still longer course of years; for like old wine the interest of such records constantly multiplies as time rolls on.

\section{The Problem of Maintaining the Fertility of the Soll.}

It is the great problem which has puzzled the farmers of every age-how best to maintain the fertility of the soil under the constant drafts it is obliged to sustain to meet the daily wants of man and beast. In a new land the virgin luxuriance which at first requires no artificial aid from the manure heap, and perhaps seems almost inexhaustible, after a crop or two,-or it may be, not until after a considerable series of years-shows signs of diminished productiveness; - and then it is soon discovered that Art must come to the assistance of Nature--that the soil must be fed as well as bled-that the old, old study which dates back some thousands of years before the parable was narrated of the barren tree that required to be "digged about and dunged," must be renewed and again investigated, under changing conditions, but in accordance with unchanging principles. As the Agriculture of a country grows still older, this question of manures and manuring, becomes more and still more the sulject of discussion among its Farmers. We, in New York, are as yet but just upon the threshold of the question. We look around us upon here and there a locality, or perhaps a single farm, which has been "run down" by over-cropping,- - where the farmers, like their land, are now poor-and, again, upon occasional instances of well sustained production and prosperous farmers,and we are beginning to learn that in the one case proper attention to manuring has been invariably neglected -in the other, that it has been, just as invariably, the object of unceasing care and judicious expenditure. The logical comnection between abundant compost-piles in well-managed barn-yards, and heavy granaries or well-filled hay-mows, it seems almost uniformly to require a generation or two, thoroughly to establish; and even now, as much as we hear it discussed on such occasions as this -as much as we read about it in our agricultural papers-one would certainly think, to judge from far too many farmsteads we pass by on every public road I have ever travelled, that the agri 
cultural mind was not yet quite clear as to the cardinal necessity of economizing and liberally applying manurial substances.

\section{Anmal Life Becoming in turn the Support of Vegetable LIFE.}

The philosophy of vegetation-the connection between the constituents we find in the soil, and those which make up the plant grown upon that soil-is not yet perfectly understood, even by those who have devoted the most time to its investigation. It seems to be even now, for example, an undecided point whether the rootlet can take up its food, except in a state of solution; and we might almost say that the old theory of Jethro 'Tull - the extreme comminution of the particles of the soil by thorough tillage, as supplying nourishment in a form directly available for the plant-has been revired in substauce, although under a somewhat different guise, by writers of recent date.* The doctrine announeed when chemists began to promise so much aid to the firmer, - that we only need to analyze first the soil and then the plant, to know exactly what is wanting to increase the power of the one to produce the other, has been exploderl for, between two fields, of which one is almost barren, and the other has been rendered capable of yielding a heavy cropl liy a dressing of a few cwt. of guamo, there is not chemical difference enough to be detected in an ordinary analysis by the nicest appliances that Feience has yet placed in our hands.t One learned man, who has expended a lifetime in the laboratory and in out-loor experiments, will tell us that we must replace in the land the mincrals which our crops are yearly carrying off; another that it is nitrogenous or ammoniacal matters that are alone essential, net only to supply the demands of the plant, but also to render the minerals-which, he will claim, are already amply ahmondant cnough in the soil-assimilable by its roots. Notwitlstanding these and other difficulties which prove so embarrassing to "diragreeing doctors," all practical men of much experience and observation, have ascertained that Nature-here, as elsewhere-is ready to conie to our relief if only the requisite degree of industry and ingenuity are put in exercise; that her machi-

* See Lrebig's Letters on Modern Agriculture-Letter III., page 37.

$\dagger$ With regard to the immediate value of Soil Analysis, even when honestly made, for the practical purposes of the farmer, see "The American Journal of Scicnce and Arts," for Sep tember, 1861-article, "Agricultural Chemistry," by Prof. S. W. JoHnson. 
nery is too well planned to wear itself out, unless we negligently disregard its laws or criminally derange its functions; that animal life and vegetable life are connected in the harmony of one great system, by that wonderful provision, which compels each in turn to become the support and sustenance of the other. Thus every farm, properly stocked and wisely managed, contains within itself the means, not only of sustaining its fertility, but also, as I believe, of developing and enlarging it, to a limit that has perhaps as yet never been fully determined.

The Resources of any Soll may be Exhausted, or, by Good Management, Rendered Practicaldiy Illimitable.

In this question of the permanently productive power of the soil, there are, as in most others, two extreme positions-one, which is in disregard both of reason and experience, and the other, which is perhaps only an exaggerated form of presenting the truth. One of our old-fashioned firmers here, or a farmer of the present day on the prairies of the West, may tell me that the nature of his soil is such that it requires no nursing-no manuring-that its fertility will never fail. Him I do not believe; eventually, - under his way of farming-his soil must, practically speaking, become "exhausted;" instead of that kind of management which shall only draw the interest, so to speak, upon the wealth that has been accumulating there for his use, during untold years, he has attacked his capital, and is erery day prodigally diminishing it. On the other hand, the chemist - the great Liebig, for instance-will argue, to take the island of Great Britain as an example-that all its mineral soilresources for the food and sustenance of future vegetation, are in fact running into the sea through its city sewers-the ultimate end of all its Agricultural production being to feed the vast crowds of humanity there congregated;-and that the entire loss of these mineral elements can only be a question of time, unless prompt means are taken to utilize the sewerage of every town and hamlet,- - just as "a well, however deep it may be, which receives no supply of water, must in the end become empty, if its water is constantly pumped out."* Him again I do not fully credit; for while the pump is pouring forth the contents of the well, there may possibly be hidden springs which he overlooks; 
the capitalist may be spending more or less every year-and yet so long as his expenditures are less than the interest which accrues upon his money, he will be growing richer instead of poorer; - and there is one sense, in which I believe the soil to be, when properly managed, illimitable in its resources-subject to no necessity of our carrying back upon it, pound for pound, exactly the materials, in weight and kind, that our crops have carried off. What land, if such were the law of regetation, has ever been, century after century, the home of man, whether savage or civilized, which would not in the end have become a desert? It has been claimed that the Chinese* really do accomplish this return to the soil of all the inorganic elements of the food which it produces, but we may be permitted to doubt whether their careful exactness in this respect has not been extolled by travellers somewhat beyond its actual desert-whe. ther, in point of fact, the manure they save and apply, is at all comparable in quantity with that which the English import from other nations in the form of guano, bones, and feeding stuffs for their animals, or mine out of the depths of their own island in the form of useful minerals or the fossil remains of extinct animal races.

How Nature may Co-operate in Maintaining and Extending THESE RESOURCES.

Perhaps you have all heard of the Grand Cathedral of Cologne, commenced more than six hundred years ago, and still unfinished. The faithful have been contributing for some time past, throughout the European dominions of the Papal Church, to arrest the progress of decay and ruin in the parts that have been standing incomplete so long, and to carry out the great designs of its first architects in all their original magnificence. Two summers ago I stood upon one of its towers, where, two hundred feet above the ground, the tops of its massive walls have lain exposed, for four or five centuries, to those agencies of wind and weather, which have been at work upon our rocks and soils ever since the world was. And here I found as luxuriant sweet briars as I ever saw growing in the fence corners of an untidy farmer in regions less etherial -with the grasses growing thickly around and under them, sprinkled over with other wild flowers; and, as I thrust

* Liebig's Letters on Modern Agriculture, page 248. 
my stick into fully three inches of as fertile looking a soil as any gardener would wish for his choicest pot-plants, I could not but ask myself-" How came they here, at an elevation too great for the wind to have deposited the dust of the streets which lie so far beneath-roses in bloom upon the surface of mason worktender grasses green, where the mortar of the builder below, unexposed to light and air, has hardened into flint?" I suppose that the mosses were the first settlers-the squatters-on this lofty and at first very unpromising territory; that, as they decayed, and the surface of the stone was corroded and disintegrated by atmospheric influences, the seeds dropped by the birds as they flew by, gave birth to other vegetation; and that thus by degrees, under the rains and snows of so many summers and winters-under the growth and decay of so many successive generations of leaves and flowers and sceds, a process had taken place, exactly analogous to that which is always going forward, on every mountain, in every valley, which the sun shines or the storm beats upon. How does an island far away from any other abode of vegetable life, in an uncrossed ocean-built up by the slow labors of myriads of coral insects, - how does such an island become clad with herbage-first a bare and untenanted cliffthen the nursery of the simpler forms of regetable growthuntil, as they moulder away, and the organic elements they have been gathering from every breeze and spray, are mingled with the abraded rock, there is a stratum deep enongh for the chance seed, left by the roving sea-fowl in exchange for the rest and shelter he has found there after some unusually adventurous flight, to grow up and mature its seed,- - until, eventually, tall and sturdy trees throw out their branches to the sky where first the moss itself could scarcely find nourishment for its tiny forest of verdure.

Tiums, if we do not Endeavor to Pump Extrayagantly, shall we not Always Find "a Supply of Water" in our Well?

And does not the very fact, that, where thus at work alone in her orm grand laboratory, Nature can effect such almost creative changes-storing up combined treasures of organic and inorganic matter in such form as to be most available for regetable reproduction, - afford sufficient evidence, if evidence be necessary, that we may devise some means by which to draw upon her accumulations, and promote her processes, in almost any soil, 
without in reality seriously trenching upon the incomparally greater stores we leave behind? And as, by thorough and deeper tillage, the atmosphere and the rains from hearen, are constantly made to penetrate more deeply and effectively into the crust of this great earth, and as the stinulants we apply in the form of manures, render these materials practically assimilable, who shall say that the uncounted generations to come, will lack that daily bread which our Father above has promised even to the raven and the sparrow? Do not all the great rivers that run into the sea, carry down in their course incalculable quantities of soil-more perhaps in the single channel of the Mississippi. of the real mineral elements of plants, than have been washed out through all the sewers of all the cities that ever were built? and yet, the old processes of Nature--cxeept in here and there a spot unusually bleak and storm-beaten-are maintaining their regular progressive round, and the world seems to be none the poorer for all this seeming loss.

\section{This Supply Renewed when the Pumping Ceases.}

The effect of the elements in promoting the vegetative faculty of the soil, is familiar to us in the case of a fallow, where, after a season of "rest," without any adclition of material from other sources, the power's of the land are in some measure evidently renerred and strengthened. So also if utterly "exhausted," as we call it, for a particular crop, after some years of respite either from all cultiration or from that single crop alone, the ingredients making up that crop will seem to have resumed such condition-mechanically, chemically or otherwise-as to be again available for its abundant production. And it thus becomes a question-but rather one involving the use of language, than of any very great practical importance at present-whether a soil is really in any sense exhausted, when by bad management it cerses to be fertile. Chemistry, unaided, would fail to determine either the extent of the so-called exhaustion, or by what particular crops it had been brought about; she might, indeed, find there all the elements necessary for plant-growth, just as she can discover little difference vetween the stony Massachusetts hill-sides and the rich bottom lands of the Scioto Talley*but one thing is very apparent, that they are not present under

* See analyses by Dr. Werls of Cambridge, quated on page 54, vol v., "Country Gentleman," 1855. 
the conditions necessary in order that they should be readily assimilable and turned to good account by the crops we desire to produce.

Illustrations in Practice-Good Farming the Surest and Cheapest.

Now, I refer to all this as proving in a general way, the bounty of Nature-that she only requires in man, as I just remarked, industry and ingenuity enough to follow the hints she gives, to reward his efforts with ample returns. And I might point you to many individual instances proving the same thing. The present President of the State Agricultural Society, George GedDes, whom perhaps many of you personally know, has a farm of 300 acres near Syracuse upon which he has kept for many years a constantly increasing flock of sheep. He has always been careful to turn all the straw he grows-and his is and has always been emphatically a grain farm, with their aid into manure; he has for instance, nearly 70 acres in winter wheat and over 70 more in spring grain; as the flock of sheep has increased, so also has his product of grain,-and although the flock must now number over 300 head, he tells me that he has no doubt he can farther increase it-even perhaps to nearly double its present size-at the same time adding to rather than diminishing his grain crops-rendering his farm each year somewhat more fertile than it was the year before-and making the prospect of each succeeding crop a surer one as regards vicissitudes of season or attacks of insects. For it is not the healthy crop well along, upon a soil in the best possible order, that is likely to suffer from any slight drawback-it has an inherent strength and vital power to withstand dangers which would prove fatal to the later and punier product of a starved and starring soil. Good farming is thus the surest farming, as it is also the cheapest farming; for every additional bushel of grain or hundred weight of hay which is grown upon an acre lessens the cost per bushel or per cwt. of all the rest-the labor being in proportion to the surface cultivated, rather than to the crop produced. Said a young farmer to me the other day- "I only mow one-half the number of acres I did four or five years agohaving let a part of my grass land for pasturage; but, by greater economy of manures, my hay crop is now as large as it was before, and I keep just as much stock the year round." There are probably similar instances within the knowledge of you all- 
affording ample illustration of the truth I have been endeavoring to enforce--that none of us have as yet fully tested the capabilities of our farms under a proper system of management. How many of us, for example, in the older settled parts of the country, have in truth better and as yet untouched farms, awaiting the plowshare and the plant-root, away down underneath the ones we have been so long and so shallowly cultivating on the top.

\section{"One Well-fed Acre morf Profitable than Three Poor-fed ACres."}

It was remarked by the late Judge Bues, in an address delirered more than 20 years ago before the Agricultural Institute of New London and Windham Counties, Conn., every word of which, however, is as true and as well worthy of attentive study to-day as when it was written, that "we better understand the " economical management of our animals than we do of plants. "We all know that we cannot make fat beef, or pork, or mutton "profitably without we feed high. It requires a certain amount " of food to keep an animal in condition-all beyond this which " the beast can consume, digest and assimilate, is virtually " converted into flesh. Now, it makes a vast difference whe"ther this extra food is converted into flesh in three months " or in twelve months; because in the former case, three"fourths of the ordinary food required to sustain life and " condition for a year, is saved to the feeder, beside an " equal expense in attendance. It is precisely so with our "crops. One well-fed acre is roore profitable than three poor"fed acres, because it requires but one-third the labor, and " will oftentimes give an equal or greater product." farmer's uniformly act upon the principles thus enunciated by Judge BueL.

Bad Faring at the Present Day less Excusable than Ever BEFORE.

In asserting as I did, that it apparently requires the experience of sereral generations to educate the farmers of a country into the liberal application of manures, I was not necessarily casting a shr upon their proverbially conservative fondness for old modes of practice. For while we are all bound to pay a certain regard to the interests of posterity, so far as not to squander

* See "The Cultirator" for December, 1839, page 194. 
the wealth-whether stored in the soil by Nature or acquired by the industry of man-of which we are in reality no more than the temporary stewards,-it is difficult to blame the cultivator of a virgin soil very severely for endeavoring to postpone as long: as possible the evil day of laborious and expensive manuring. Thus it is not impossible that, taking the farmers of the longest cultivated parts of the State as a class, they may have so farmed during past generations--with some improvident exceptions as to individuals or localities-as to have obtained for the time being and according to the measure of light they enjoyed, the most return in proportion to the capital they had to investnot always, however, most wisely in view of the profits of those who were to succeed them. And yet there were, in the days of our fathers as now, without doubt, occasional instances of careful observation and thorough-going practice, to one or more of which the memories of us all may possibly extend-instances of success, then too often ascribed to mere "good luck," which, if they had been brought down in detail to the present day, might have been found to foreshadow nearly everything which we can even now include under the comprehensive title of GOOD FARMING. On the other hand, then as now, lands that proved suitable for some one crop were kept under that crop year after year in a most suicidal way, until it could no longer be produced; then as now, many of the simplest dictates of reason were overlooked from lack of thought-from mental rather than bodily inaction or slothfulness-but now there is less excuse than then, for the existence of such faults among us, and as they have been brought into strong contrast with the principles and practices of a wise, far-seeing and money-making Husbandry, as displayed in the columns of our Agricultural papers, and through the medium of our Agricultural Exhibitions, it is scarcely surprising that we have sometimes seemed to be constantly growing worse and worse than our fathers, instead of simply to be improving so little upon the example they set before us.

\section{Average Crops as Estimated Sixty or Seventy Years Ago.}

As to the real averages of the crops produced in this country in former years, we find that Gen. Washington, in 1790, in a letter to Sir John Sinclair, computed the average crop of Pennsylvania, which State he selected as showing the highest degree of cultivation then attained among us-as 15 bushels of wheat per 
acre, 20 of rye, 30 of oats, 25 of Indian corn, 75 of potatoes; and Mr. Strickland, an eminent British farmer who resided in this comtry some time, near the close of the last or the beginning of the present century, in a communication to the British Board of Agriculture, stated our average wheat crop at 12 bushels per acre, except in Duchess County in this State, which was then a great wheat growing region, where he considered the average return equal to 16 bushels per acre.* These figures accord so nearly with the best estimates of our general average production now, that we are forced to look for whatever improvement there has been, in some other direction than in the actual amounts of giain harvested per acre-and we shall find evidences of its existence, I think, in the extension of our grain crops upon lands which were at one time thought totally unproductive of them-in the care taken of our grass lands and the better results thence obtained,-in cheapening the cost of what we do raise, by the adoption of better implements and of horse machinery; in the greater and more skillfully directed attention now paid to dairying and to other particular branches of farming, where a demand has arisen for them; in fine, in preparing the way, by slow stages, for a still more progressive future, as we come to learn, with every recurring year more and more thoroughly, the importance of deeper cultivation and regular manuring, and as the old idea of a change of location every little while, gradually dies aray, and farmers who inhabit the homesteads of their fathers, look upon them as likely to become also the homesteads of their sons and grandsons.

The Course of our Population does not Prove the "Decay of our Agriculture."

And if our rural population has increased less rapidly than that of our cities and towns, and in here and there a case actually shown a slight falling off,--here again there are two important considerations which we must not overlook: In the first place, we can with difficulty estimate the number of those whose absence from farm-labor is fully made up to us in rarious ways -by the immense numbers of reapers and mowers we now employ, by the use of machinery in thrashing and the substitution of cultivators instead of the hand-hoe, and by the vast

* See Judge BuEL's Address before the New Jersey Stato Agricultural Society, published in "The Cultivator" for November, 1839, page 178. 
saving in the time required to market the products of the farm when it is done by railroad or steamboat, instead of teaming. them a score or two miles over heary wagon roads, anc? spending perhaps a week to do what a letter will to-day accomplish by "return of mail." In the second place, there are many drawn away from the rural districts, who when there never belonged strictly to the farming population of the country: the railroads and other infuences are constantly centralizing many kinds of industry in the cities which were formerly carried on to better advantage in villages, or indeed at every cross-road. The implements of the farm, from the plow all the way through the list, formerly were made singly by scattered smiths and mechanics, instead of by the wholesale in huge factories; the clothing of the farmer, from his hat to his boots, was more generally cut and put together, if not its very materials manufactured, almost at his door, instead of coming ready-made from distant cities and towns; in fine, access to the great marts has been rendered so easy that much of the trading eren has left the rillages for more central and important points. In all these wars, the cities hare gained at the expense of the country-not at the expense of the farm; while the farmers have gained all the time in the more general adoption of improved machinery; in increased consumption of their products, and in the power of obtaining better manufactures at lower prices.

Economy of Manures as the Mainspring of all AgriculTURAL IMPROVEMENT.

During the three summer months of $1859 \mathrm{I}$ had perhaps unusually farorable opportunities of intercourse with some of the best farmers both of England and Scotland. The more I saw of their methods of management, the more deeply I was impressed with the neglect and wastefulness which characterize our treatment in America of manurial materials, as contrasted with the attention, labor and money there so profusely expended upon this object. And, comparing the condition of English Agriculture as represented to us by Arthur Yousg eighty years ago, with its present character, we cannot but come to the conclusion that it is precisely in this direction that the most improvement has been accomplished-herein, at least, that the changes which have successively occurred have been most marked, both in their nature and results, until the English farmer has come to regard 
his supply of fertilizers as the mainspring of every other operation-the one central motive power that regulates and directs everything else he undertakes. The extent of surface each year devoted to the feeding crops, clovers and the roots, has been constantly gaining in proportion to that deroted to the cereals constituting the food of man-in other words the true secret of increasing the wheat crop was found to be-not necessarily to sow and reap more acres, by any means, but to put a larger surface under crops which could be turned into manure for the wheat fields. This is what is going on step by step, mpon our best farms here. What is the case of Mr. Gednes, to whom I have already referred, but an instance in point-ever increasing the stock upon his land, but also increasing his grain crop,-not by devoting a larger surface to the latter, but by enriching that surface, and even diminishing its extent as it grows richer in quality? You have, perhaps, heard of the old Scotchman, who, in response to a young farmer seeking his advice as to the true secret of success in his pursuit, summed up the experience of his own life, in this pithy and comprehensive warning: "Never, SANDIE, never-above all things, Never go into debt, but if ever you do go into debt, let it be for Manures!"

Peccliar Adyantages of our Dairy Regions in this Respect.

The study of British Agriculture, in its onward career, let me once more repeat-not less than what we may note of success and failure among our own farmers-must thus lead us to hinge almost every question of progress and improvement-I leave you to determine, from your own experience, how justly-mpon the one great and orer-ruling question of Manures and Manuring. It is in this, as I just intimated, that the deficiencies of our farming strike the observer from abroad most pointedly-in this that we seem to be perhaps eighty or a hundred years behind Great Britain. What opportunities, too, are enjoyed, especially in the Dairy regions of the state, for the enrichment of the land: deriving a ready source of profit from the animals of the farm, their contributions torards its increased fertility cost little if anything beyond the legree of labor and attention required to preserve and apply what they cannot choose but give; and there is not the excuse for neglect in this regard, which sometimes does exist, where it is necessary to strike a balance, on the one hand, between the services of cattle or sheep in the 
manufacture of manures, and, on the other, the loss resulting from their keep, owing either to the high prices at which they are bought, or to the money-value of what they consume. But after due allowance for the importance of these services, I know of no locality in which there would be any doubt upon which side the balance of loss or gain must ultimately turn-none, in which the farmer can afford to neglect the domestic animals of the farm as the means of permanently sustaining its productive powers. And, as we look over the Agricultural capacities of our own and the other Eastern States, as yet so imperfectly developed, and find the first flush of virgin wealth already faded from so large a portion of their surface, while cheaper beef and wheat than we can raise without a better system of management, are coming down upon us over the great railroad lines that now link the harbors of New York and Boston with every portion of those vast regions where, in the days of our fathers, the Bison and the tomahawk were far more at home than the Short Horn and the reaper's sickle,-this question of manures-involving the question of making the most of our land for present and future years-acquires new grandeur and importance to us, and the example of our English brethren becomes still more worthy of our study and imitation.

A Prosperous Agriculuture the Foundation of all National Prosperity-the Existence of the One proves the ExistENCE OF THE OTHER.

If I have succeeded in making my meaning sufficiently clear to have been followed during the preceding train of thought,- -you will have discovered that my main object has been to point out the sources of encouragement-the incentives and exigencieswhich now urge upon the Farmer-especially the Farmers of New York-renewed efforts for Betrer Farming. Standing in an emergency new to our experience, unprecedented in the history of the world-believe me, gentlemen, the condition of our country, the progress of our Agriculture, the current rates for our products, all admonish us that this is no time to neglect the Farm-to pause or turn back in the career of improvement. As to the part which the Farmer has taken in the past history of our National Growth and Progression, there can be no doubt. If time allowed me to trace it on this occasion, you would ask no farther evidence that whatever promotes the farmer's prosperity 
must give a fresh impulse to every channel of business-buoyancy to trade, activity to manufactures, food to the hungry of other nations, money to be expended in our own, in perfecting old enterprises and in undertaking new ones. In that history, as a whole, it is no gloomy picture that I should have to present,of lands exhausted and abandoned-of fertility exchanged for barrenness-of straggling briars and worthless underbrush starving over a surface once waving with grain and grass. It is no sad outline of a population constantly growing more prolific and more indigent; of a peasantry gaining nothing in intelligence, if not separated by a line every day broader and more impassable, from the acquisition of knowledge and the chances of advancement; of children bred to ill-rewarded toil or shiftless indolence where their ancestors were in comfortable and thriving industry; of a state of Society in which labor involves disgrace, because disgracefully paid, if not disgracefully done; of this labor ever descending more and more nearly to the level of that which the brute is trained to perform, for the lack of mind and of encouragement for its exercise. All this and more, we may find in many another land-Thank God that here the truth is, and has always been, far different! Such is the almost inevitable record of a country whose Agriculture is in reality going backward-whose soils are in truth becoming exhausted-whose farming is the task of the menial or the serf. How great the contrast between such a history and that which the descendants of the Pilgrim Fathers have wrought out! What but their farming has transformed the whole face of this broad land from a wilderness to fruitful fields? What, if not farming, has fed and clothed and schooled the masses of our people-constructed our Academies, Colleges, Churches and public buildings-yes, and built up the greatness of our Cities by supplying them with fresh blood and brains, educated by its profits-and unweakened by their cares and dissipations? Agriculture is the immediate sire of Commerce; and the wealth of the merchant and the manufacturer finds its first sources in the wealth of the farmer. The prosperity of those who buy and sell, or re-shape the raw material for human use, is so dependant upon the prosperity of the great class which produces, that the statistics which prove the vast growth of our commercial transactions, conclusively prove-not that in here and there an instance our farmers have been successful-but that success has been the rule instead of 
the exception-that the producing classes have been constantly enabled to indulge in new luxuries and expend more money, and that, as a whole, both they and the country at large have been rapidly growing richer and richer.

\section{What is to be the Future of this Career?}

And now, gentlemen, I will detain you but a moment longer. If it is true in ordinary seasons that a prosperous and well-conducted Agriculture is the mainstay of a country, how much more is such the case in the trying circumstances in which we are now placed. The rule or ruin policy which has apparently been the source on the part of the South, of the present National difficulties, is one which, once admitted, must be the destruction of any form of government. It can only survive in the death of republican liberty. It can only triumph in the ruin of popular rights-in the extinction of that faith in self-government wherein the grand authors of our independence fought and conquered. By the ordering of Providence, we have a most striking example of its inevitable results in our sister republic of Mexico, in which civil war seems to have become a chronic difficulty - a part of the established order of things. No expense can be too greatno sacrifice too costly, as bulwarks against such a flood of misery, anarchy and destruction. I know this is no place to discuss questions of public policy, or to mingle the clamors of war, with the peaceful sounds of rural industry. But in such an emergency as this, private pursuits or party lines should become the means of linking us all closer, as rivals only in patriotic fervor; -looking back upon the glorious career of those who first established our independence, in its defence let us emulate their exertions. Remembering "how dark a night it was that preceded the dawning of our National existence," let us not despair because its sunlight may be obscured by the passing tempest, its strength and manhood subjected to their first great test. The success of the right-the vindication of the ballot-box as the index of the popular will-the re-establishment of the Federal power, in all its former length and breadth and grandeur, can be no more than a question of time, if we are really united and in earnest,--worthy to enjoy the inheritance we have received, and determined to transmit it, unimpaired and untarnished, to those who are to come after us! 

